\title{
Huge Brenner's Tumour of Ovary (6.2kg) in a Postmenopausal Female - a Rare Case Report and Review of Literature
}

\author{
Rajshree Dayanand Katke ${ }^{1 *}$ and Sivanandini Acharya ${ }^{2}$ \\ ${ }^{1}$ Medical supritendent Cama Albless hospital, JJ group of hospitals, India \\ ${ }^{2} J u n i o r$ resident department of obstetrics and gynecology, Grant government medical college, India
}

Submission: January 06, 2017; Published: February 02, 2017

*Corresponding author: Rajshree Dayanand Katke, Medical suprintendent Cama Albless hospital, India, Email: drrajshrikatke@gmail.com

\begin{abstract}
Transitional cell tumors of the ovary, described for the first time by Brenner in 1907, are one of the rare neoplasms of all ovarian tumors and account for nearly $2 \%$. Transitional cell tumors, in turn, include two distinct clinico-pathological subtypes: Transitional cell carcinomas (TCCs) and Brenner Tumors [1].

The World Health Organization (WHO) classifies Brenner tumors into three categories: benign, borderline and malignant. Borderline Brenner tumors, usually associated with a benign Brenner tumor, are characterized by papillary structures with a fibro-vascular core covered by a transitional epithelium. In $30 \%$ cases Brenner tumour is associated with mucinous or serous cystadenoma. We report the case of a 68-year-old woman with a left ovarian mass, for which the morphology and histopathological analysis was consistent with the diagnosis of Brenner tumor associated with mucinous cystadenoma.
\end{abstract}

Keywords: Transitional cell tumors (TCCs); Brenners tumor; Mucinous cystadenoma; Histopathology; World Health Organization (WHO)

\section{Introduction}

Brenners tumors are subgroup of transitional cell tumors. They are generally unilateral, only 5-7 \% cases are bilateral. Sometimes brenners tumor is associated serous or mucinous cystadenomas. They are usually asymptomatic, may be diagnosed as an incidental finding. When associated with cystadenomas, they may present as large ovarian masses which may present mainly with the pressure symptoms over the genitourinary system leading to urinary complaints and also pressure over respiratory system leading to respiratory embarrassment [2].

It is generally accepted that Brenner tumors are derived from the surface epithelium of the ovary or the pelvic mesothelium through transitional cell metaplasia to form the typical urotheliallike components. Brenners tumor is a histopathological diagnosis. Microscopically it is characterised by abundant dense fibrous stroma with epithelial nests of transitional cells with coffee bean shaped nuclei resembling those lining the urinary bladder. Surgical resection of the tumor mass is diagnostic as well as curative for this tumor.

\section{Case Report}

A 67 year old postmenopausal multiparous female presented to our hospital with complains of pain in abdomen since 1 month and distension of abdomen since 6 months. Patient was a known case of hypertension and hypothyroidism and was under treatment for the same. On examination her vitals were stable and no abnormality detected on general and systemic examination. Per abdominal examination revealed a mass of around 32 weeks size gravid uterus. It was firm to cystic in consistency with smooth surface and restricted mobility arising from pelvis and extending upwards to xiphisternum. On per speculum examination revealed cervix and vagina healthy.

On per vaginal examination mass of 32 weeks size felt, origin of which could not be detected. Ultrasonography showed a complex multicystic mass of $25 \times 11 \times 10 \mathrm{~cm}$ arising from left ovary, uterus and right ovary were normal. Magnetic Resonance Imaging revealed complex left ovarian neoplasm with enhancing solid and peripherally enhancing cystic components measuring $25.3 \mathrm{~cm} \times 16.9 \mathrm{~cm} \times 10.5 \mathrm{~cm}$ with minimal sfree fluid and no lymphadenopathy.

Tumour markers showed CA 125 level was mildly raised and was $96.76 \mathrm{Iu} / \mathrm{ml}, \mathrm{CEA}$ and AFP level were within normal limits. Exploratory laparotomy was done which showed a huge left ovarian cystic mass of size $25 \mathrm{cmx} 18 \mathrm{~cm} \times 15 \mathrm{~cm}$, rest of abdominal and pelvic organs were normal. In situ findings were revealed 
huge Left ovarian mass of size 32 weeks gravid uterus, huge one soft to firm in consistency with smooth surface without any surface excreations. Removal of huge left sided ovarian tumour done after dissection of ureters to avoid damage.to it. Total abdominal hysterectomy and Right salpingoophorectomy was done. Cut section showed a cystic mass filled with mucinous material with solid components. Frozen section suggested a diagnosis of mucinous cystadenoma with Brenner components.

Microscopic examination revealed a cyst lined by a single layer of non-ciliated columnar epithelium without stromal invasion and solid component showed nests of ovoid to polygonal transitional cells like epithelium and have pale cytoplasm and oval nuclei. Final Histopathology report confirmed the diagnosis of mucinous cystadenoma with Brenner component. Post operative period was uneventful and patient was discharged in Healthy condition. On follow up patient recovered well and resume the activities.

\section{Discussion}

Brenner tumor of ovary is a solid ovarian tumor that is generally asymptomatic. Although they are predominantly solid on imaging and pathologic examination, association with serous and mucinous cystadenomas is up to $30 \%$ [3]. It is usually an incidental pathological finding. Among symptomatic patients, common symptoms include vaginal bleeding, a palpable pelvic mass, and pelvic pain. Most of the time it is found to be unilateral. Bilaterality is seen only in $5-7 \%$ of the cases. It is generally accepted that Brenner tumors are derived from the surface epithelium of the ovary or the pelvic mesothelium through transitional cell metaplasia to form the typical urothelial-like components [4]. The histological patterns observed in Brenner tumor are typically benign, with a few reports of borderline or malignant counterparts [4].

It is difficult to diagnose Brenner tumor with imaging studies as the findings are non specific [5]. USG and computed tomography, both the techniques are limited in specificity because of the tumor's nonspecific appearance. In imaging studies benign Brenner tumors are generally similar to those of other solid ovarian masses such as fibroma, fibrothecoma, and pedunculated leiomyoma [3].

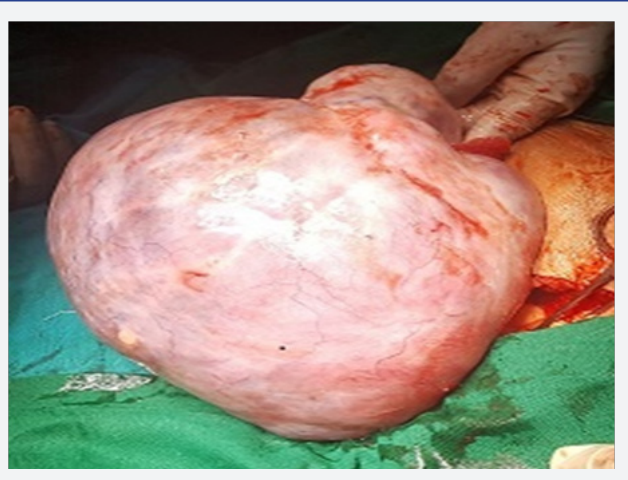

Figure 1a: Intraoperative picture of huge brenners tumor $(6.2 \mathrm{~kg})$.
Grossly benign Brenner tumors are well circumscribed, with a hard or fibromatous, gray, white, or slightly yellow cut surface. Occasionally the tissue becomes gritty because of calcific deposit. Borderline Brenner tumors are characteristically cystic and unilocular or multilocular with cauliflower like papillomatous masses protruding into one or more of the locules. Malignant Brenner tumor may be solid or cystic with mural nodules; they usually do not have any distinctive features (Figure 1a\&1b).

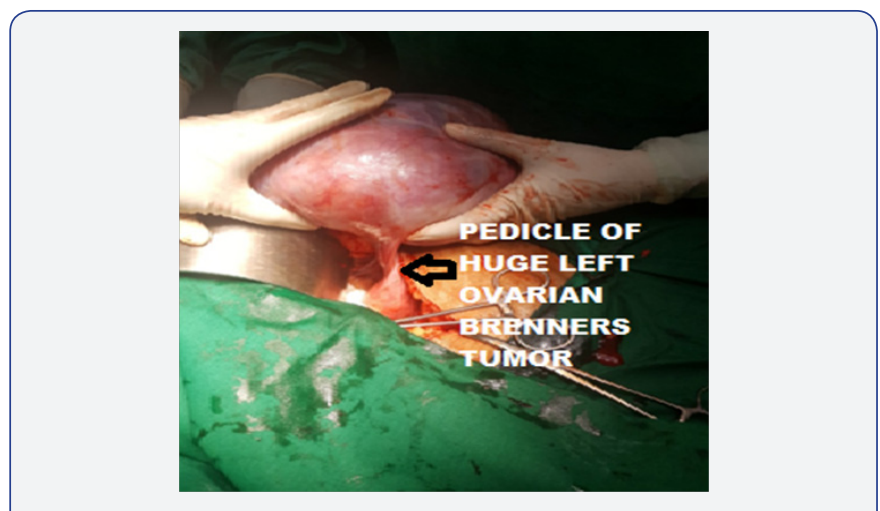

Figure 1b: Intraoperative picture of huge brenners tumor (6.2kg).

Microscopically, they are made of abundant dense fibrous stroma with epithelial nests of transitional cells resembling those lining the urinary bladder. The fibrous component is less prominent in borderline or malignant tumors than in benign lesions. Complex cystic tumors contain varying amounts of stroma and are more commonly found with borderline or malignant histologic findings, often in the form of papillary solid projections within a cystic mass.

Immunohistochemistry and molecular analysis is helpful in diagnosis and confirmation of Brenner tumour but considering high cost is not of much clinical value. Borderline Brenner tumors are negative for $\mathrm{p} 16, \mathrm{Rb}$ and $\mathrm{p} 53$, and show weak immunostaining for Cyclin D1, moderate for Ras and strong for EGFR. They also express p63, as in benign subtypes but not in malignant ones, and present a diffuse staining for CK7, CA125, thrombomodulin and EMA, as in all subtypes of Brenner tumors [1]. Malignant Brenner tumor is also negative for $\mathrm{p} 16, \mathrm{Rb}$ and p53, but strongly positive for EGFR, Cyclin D1 and Ras (Figure 2).

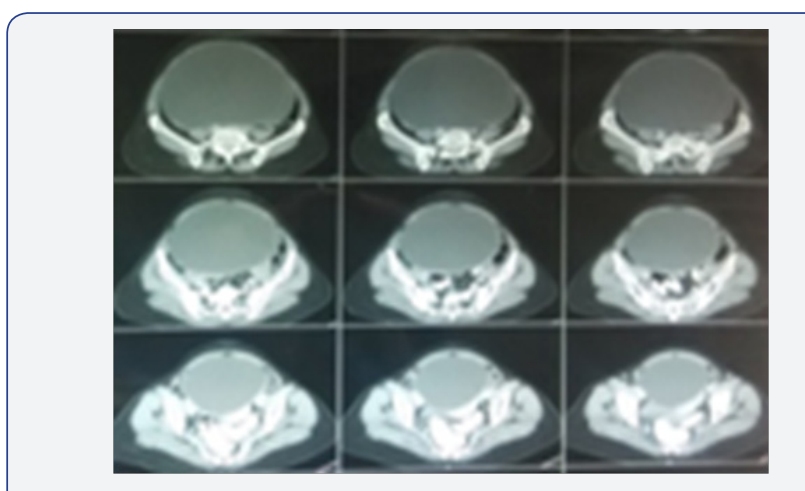

Figure 2: Computerized Tomography Scan of huge Brenners Tumor. 


\section{Conclusion}

We hereby present a rare case of a huge brenners tumor of $6.2 \mathrm{~kg}$ which presented in a postmenopausal female. Histopathological examination is most important in diagnosis of Brenner tumour apart from radiological investigations and immunohistochemistry. Most Brenner tumors are candidates for surgical resection. Surgical resection is often diagnostic as well as curative and will reverse symptoms if they are present.

\section{References}

1. Hemalatha AL, Konanahalli P (2005) Bilateral malignant Brenner tumor of ovary. J Obstet Gynecol India 55(1): 81-82.
2. Katke RD, Kiran U, Saraogi M, Sarode S, Thawal R (2014) Giant borderline mucinous cystadenoma with previous 3 caesareans. J Postgraduate Gynaecol Obstet 1: 1-4.

3. Green GE, Mortele KJ, Glickman JN, Benson CB (2006) Brenner tumors of the ovary sonographic and computed tomographic imaging features. J Ultrasound Med 25(10): 1245-1251.

4. Arey LB (1961) The origin and form of the Brenner tumor. Am J Obstet Gynecol 81: 743-751.

5. Katke RD (2015) Huge mucinous cystadenoma of ovary with massive third degree uterovaginal prolapse in postmenopausal woman: rare case report and review of literature. Int J Reprod Contracept Obstet Gynecol 4(1): 255-258.

\section{Your next submission with Juniper Publishers} will reach you the below assets

- Quality Editorial service

- Swift Peer Review

- Reprints availability

- E-prints Service

- Manuscript Podcast for convenient understanding

- Global attainment for your research

- Manuscript accessibility in different formats (Pdf, E-pub, Full Text, Audio)

- Unceasing customer service

Track the below URL for one-step submission https://juniperpublishers.com/online-submission.php 